\title{
Studies of jejunal mucosal digestion of peptic-tryptic digests of wheat protein in coeliac disease
}

\author{
FRED E. PITTMAN ${ }^{1}$ AND RODNEY J. POLLITT \\ From the University Departments of Medicine and Physiology and the \\ M.R.C. Unit for Research on the Chemical Pathology of Mental Disorders, \\ Birmingham
}

EDITORIAL SYNOPSIS These studies have demonstrated an abnormality of peptidase activity in the jejunal mucosa in coeliac disease. It is not yet certain whether this is a primary basic change or secondary to as yet undetermined causes.

The aetiological relationship of wheat gluten and gliadin, and some peptides obtained from them by peptic-tryptic digestion, to the clinical and small intestinal mucosal abnormalities of coeliac disease has been demonstrated in several studies (Dicke, 1950; Anderson, Frazer French, Gerrad, Sammons, and Smellie, 1952; Sheldon and Lawson, 1952; Dicke, Weijers, and van de Kamer, 1953; van de Kamer and Weijers, 1955; Schwartz, Sleisenger, Pert, Roberts, Randall, and Almy, 1957; Krainick, Debatin, Gautier, Tobler, and Velasco, 1958; Krainick and Mohn, 1959; Frazer, Fletcher, Ross, Shaw, Sammons and Schneider, 1959; van Roon and Haex, 1960, Bayless, Yardley, Norton, and Hendrix, 1962; Rubin, Brandborg, Flick, Phelps, Parmentier, and van Niel, 1962; Pittman and Holub, 1965). The mechanism of the harmful action of wheat protein and the peptides remains obscure. It has been suggested that the small intestinal mucosa of patients with coeliac disease may be deficient in peptidase activity, and therefore unable to degrade normally certain peptides derived from intraluminal digestion of wheat protein (Frazer, 1960; Rubin, 1960; Laster and Ingelfinger, 1961). Only one quantitative study of peptidase activity of small intestinal mucosa obtained from patients with coeliac disease has been reported (Messer, Anderson, and Townley, 1961). No abnormalities of peptidase activity were found when nine different synthetic peptides were used as substrates.

The studies reported in this paper were carried out to determine if small intestinal mucosal homogenates obtained from patients with untreated adult coeliac disease degrade peptides derived from

${ }^{1}$ Address requests for reprints to: Fred E. Pittman, M.D., Department of Medicine, Tulane University School of Medicine, 1430 Tulane Avenue, New Orleans, La. 70112, U.S.A. peptic-tryptic digestion of gliadin in a manner different from mucosal homogenates of guinea-pig and normal adult human jejunum.

\section{PATIENTS AND METHODS}

Jejunal mucosal specimens were obtained from three adult patients with untreated coeliac disease with the Crosby-Kugler intestinal biopsy capsule. In each instance the position of the capsule was checked radiologically and shown to be at, or just beyond the ligament of Treitz. The diagnoses of coeliac disease were well documented clinically and by laboratory tests. All three patients had previously had jejunal mucosal biopsies which showed severely flattened mucosa with abnormalities of the surface epithelial cells, histological findings characteristic of coeliac disease. Each of the three patients subsequently showed clinical improvement when treated with a gluten-free diet. Two normal human jejunal mucosal specimens, also obtained by peroral biopsy, were used as human control material. Each biopsy specimen was weighed and homogenized by hand with $0.5 \mathrm{ml}$. of isotonic saline and $0.5 \mathrm{ml}$. of $5 \%$ glucose. The specimens were of comparable weight (35-50 mg.). Guinea-pig jejunal mucosa was obtained by rapidly removing the small intestine from freshly killed adult guinea-pigs, opening the intestine, washing the mucosal surface with cold isotonic saline, blotting gently with filter paper, and scraping off the mucosa with the edge of a glass slide. Homogenates were prepared which contained $50 \mathrm{mg}$. of mucosa per millilitre of the isotonic saline-5\% glucose solution. All of the preparative procedures were performed at $4^{\circ} \mathrm{C}$.

A preparation of gliadin ${ }^{2}$, the alcohol-soluble fraction of wheat gluten, was first tested for toxicity by instillation experiments reported elsewhere (Pittman and Holub, 1965). Peptic-tryptic digestion of heat denatured gliadin was carried out with twice-recrystallized pepsin ${ }^{2}$ and crystalline trypsin ${ }^{2}$, using the methods of Frazer et al. (1959), except that $\mathrm{NH}_{4} \mathrm{HCO}_{3}$ was used to achieve an

Obtained from Mann Research Laboratories, New York, N.Y., U.S.A. 
appropriate alkaline $p \mathrm{H}$ for the trypsin digestion. After completion of the digestion the solution was taken to dryness and the $\mathrm{NH}_{4} \mathrm{HCO}_{3}$ was removed under reduced pressure. The peptides were then dissolved in distilled water. This solution, which was used as substrate for subsequent digestions with mucosal homogenates, contained $9.85 \mathrm{mg}$. $\mathrm{N}$ per $\mathrm{ml}$. as determined by the Kjeldahl method and was at $p \mathrm{H} 6.5$. To $0.5 \mathrm{ml}$. of the peptide mixture was added $0.5 \mathrm{ml}$. of the mucosal homogenate. Incubation was performed in narrow test tubes at $37^{\circ} \mathrm{C}$. for 60 minutes with gentle shaking. The digestion was stopped by immersing the tubes in boiling water for five minutes. The tubes were then cooled in tap water and the mixture centrifuged at $3,000 \times g$ for 15 minutes. The supernatant was kept frozen at $-20^{\circ} \mathrm{C}$. for subsequent preparation of digestion maps. Appropriate substrate and enzyme control digestions were carried out simultaneously.

Digestion maps ('fingerprints', peptide maps) were prepared as follows. First, an appropriate quantity of the mixture was subjected to electrophoresis ${ }^{3}$ at 40 volts $/ \mathrm{cm}$. for 90 minutes in a volatile buffer (pyridine, $0.4 \%$ and acetic acid, $0.8 \%$ in water: $p \mathrm{H} 4.4$ ) on Whatman $3 \mathrm{MM}$ paper strips suspended in white spirit as coolant. After being dried overnight at room temperature in a fume cupboard, the strips were sewn on to large sheets of Whatman 3MM paper and a second dimension run as a descending chromatogram in butanol: acetic acid:water (12:3:5) for 16 hours (Smith, 1960). After they had again dried, the chromatograms were dipped in $0.2 \%$ ninhydrin in acetone and left overnight at room temperature to develop. Subsequent heating at $90^{\circ} \mathrm{C}$. for one hour failed to bring up additional spots.

Further resolution of the neutral band of peptide spots was accomplished by cutting out the neutral band of an undeveloped duplicate two-dimensional digestion map and sewing it to another large sheet of Whatman 3MM paper. This was then run as a descending chromatogram in phenol:ammonia:cyanide (Smith, 1960) and was also developed with ninhydrin.

\section{RESULTS}

SUBSTRATE DIGESTION MAPS Two-dimensional digestion maps of the peptic-tryptic digested gliadin substrate (substrate maps) showed both discrete spots and a neutral band of poorly resolved spots. There was also diffuse ninhydrin-positive material about the spots in the neutral band (Fig. 1a). Good resolution of the spots in the neutral band was obtained with the third dimension (Fig. 1b).

NORMAL HUMAN AND GUINEA-PIG JEJUNAL MUCOSAL DIGESTION MAPS The digestion maps obtained with homogenates of both normal human and guineapig jejunal mucosa were identical and comparison with the gliadin substrate maps revealed that further digestion of the peptides had occurred (Figures $2 \mathrm{a}$ and $2 \mathrm{~b}$ ). Some spots in the substrate maps had

${ }^{3}$ High-voltage electrophoresis apparatus supplied by Gilson Medical Electronics, Middleton, Wisconsin, U.S.A.

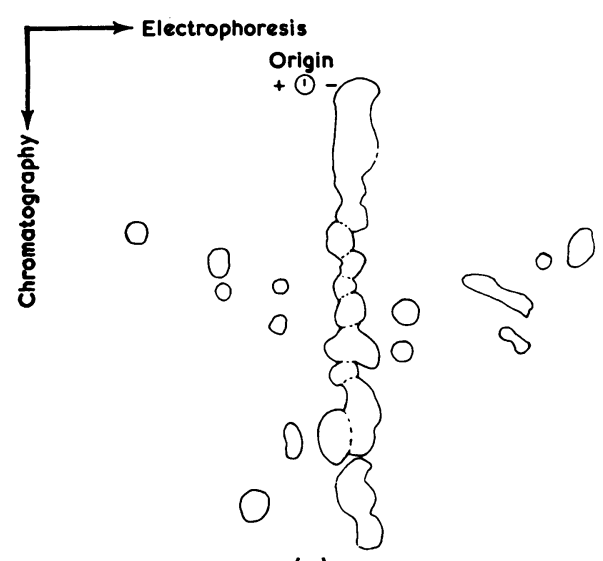

(a)

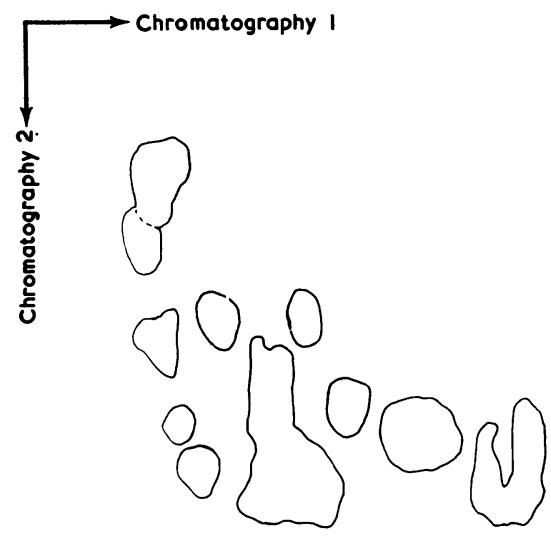

(b)

FIG. 1. Tracings of digestion maps of pepsin-trypsin digested gliadin (substrate maps).

FIG. 1a. Two-dimensional map.

FIG. 1b. Neutral band run in third dimension.

disappeared, the intensity of others had decreased, the diffuse ninhydrin-positive material about the neutral band was no longer present, the spots in the neutral band were more clearly defined and more intense, and new spots were present, including two yellow spots (Y1 and Y2) in the neutral band. One of these spots corresponded to the position of proline (Y2). When the three-dimensional digestion maps were compared with that of the substrate they were found to show differences in the relative positions of some of the spots, the appearance of new ninhydrinpositive spots, and the disappearance of spots which were present in the substrate map. The spot Y2 was isographic with proline in this solvent system. 

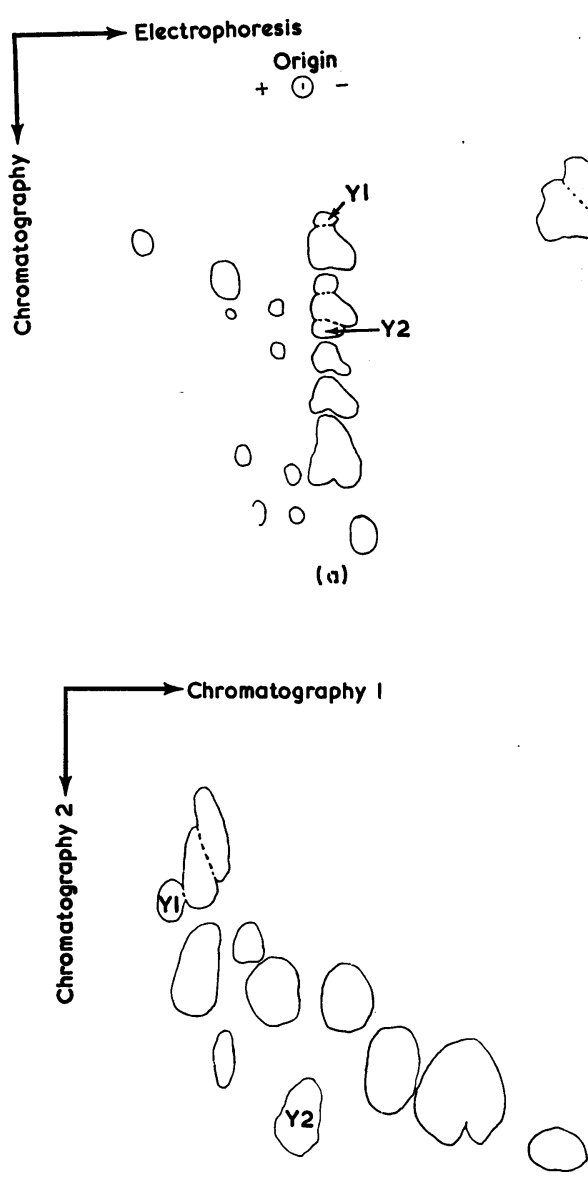

(b)

FIG. 2. Tracings of digestion maps obtained by further digestion of gliadin peptides by homogenate of normal human jejunal mucosa.

FIG. 2a. Two-dimensional map.

FIG. 2b. Neutral band run in third dimension.

COELIAC DISEASE JEJUNAL MUCOSAL DIGESTION MAPS Two- and three-dimensional digestion maps obtained using jejunal mucosal homogenates from the three patients with untreated coeliac disease were identical and were unlike both the digestion maps obtained from normal human and guinea-pig jejunal mucosal homogenates (Figs. $3 a$ and $3 b$ ). Spots which were present in the substrate map had disappeared and new spots were present. When the coeliac disease mucosal digestion maps were compared with those of the normal human and guinea-pig mucosal homogenates, it was found that there was less clearing of the diffuse ninhydrin-positive material in the region.

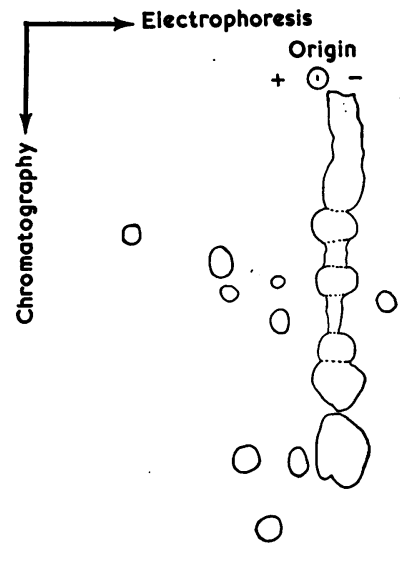

FIG. 3. Tracings of digestion maps obtained by further digestion of gliadin peptides by homogenate of untreated adult coeliac disease jejunal mucosa.

FIG. 3a. Two-dimensional map.

FIG. 3b. Neutral band run in third dimension.

of the neutral band and that spots which were present in the normal were absent in the coeliac digestion maps. Neither of the two yellow spots was present in the coeliac maps.

\section{DISCUSSION}

These studies indicate that under in-vitro conditions homogenates of normal human and guinea-pig jejunal mucosa digest peptic-tryptic peptides of gliadin in a manner different from homogenates of similar mucosa obtained from patients with untreated adult coeliac disease. The failure of the 
coeliac disease mucosal homogenates to liberate detectable quantities of proline from the gliadin peptides is of special interest because of the suggestion that the gliadin peptides which are toxic to patients with coeliac disease contain this amino acid (Krainick and Mohn, 1959). Although these findings may reflect a basic, primary abnormality of peptidase activity in coeliac disease jejunal mucosa, it is possible that the abnormality, like the intestinal mucosal disaccharidase deficiencies found in the disease (Plotkin and Isselbacher, 1964; Lifshitz, Klotz, and Holman, 1965), is secondary to as yet undetermined causes.

Further study is required to determine if the abnormalities observed are related to a general decrease of peptidase activity, if they are present in coeliac disease jejunal mucosa that has regenerated following treatment with a gluten-free diet, and if they are reflected in abnormalities of digestion maps of non-toxic dietary proteins predigested with pepsin and trypsin and used as substrate with coeliac disease jejunal mucosal homogenates.

\section{CONCLUSIONS AND SUMMARY}

Multidimensional digestion maps ('fingerprints', peptide maps) of peptic-tryptic digests of gliadin were prepared using combinations of high-voltage electrophoresis and paper chromatography. The gliadin peptides were used as substrate for further digestion with homogenates of guinea-pig, normal human, and untreated coeliac disease jejunal mucosa. Digestion maps of these preparations demonstrated that the coeliac disease mucosa digested gliadin peptides in a manner different from guinea-pig and normal human jejunal mucosa. A striking difference observed was the failure of the coeliac disease mucosa to liberate proline from the gliadin peptides. Further study is required to determine if the observed abnormalities reflect a basic, primary abnormality of peptidase activity in coeliac disease jejunal mucosa.

Grateful appreciation is expressed to Dr. J. M. French and Dr. C. W. Crane for their helpful suggestions and encouragement throughout this study and for reviewing the manuscript. Dr. Pittman is a Fellow of the Helen Hay Whitney Foundation.

\section{REFERENCES}

Anderson, C. M., Frazer, A. C., French, J. M., Gerrard, J. W., Sammons, H. G., and Smellie, J. M. (1952). Coeliac disease: gastro-intestinal studies and the effect of dietary wheat flour. Lancet, 1, 836-842.

Bayless, T. M., Yardley, J. H., Norton, J. H., and Hendrix, T. R. (1962). Adult celiac disease: rapid sequential changes in jejunal mucosa with alterations of dietary gluten. J. clin. Invest., 41, 1344.

Dicke, W. K. (1950). Coeliakie. Een onderzoek naar de nadelige invloed van sommige graansoorten op de lijder aan coeliakie. Doctoral thesis, Univ. of Utrecht.

- Weijers, H. A., and van de Kamer, J. H. (1953). Coeliac disease. II. The presence in wheat of a factor having a deleterious effect in cases of coeliac disease. Acta paediat. (Uppsala), 42, 34-42.

Frazer, A. C. (1960). The present state of knowledge on the celiac syndrome. J. Pediat., 57, 262-276.

, Fletcher, R. F., Ross, C. A. C., Shaw, B., Sammons, H. G., and Schneider, R. (1959). Gluten-induced enteropathy: the effect of partially digested gluten. Lancet, 2, 252-255.

Krainick, H. G., Debatin, F., Gautier, E., Tobler, R., and Velasco, J. A (1958). Weitere Untersuchungen über den schädllichen Weizenmehleffekt bei der Cöliakie. I. Die akute Gliadinreaktion (Gliadinshock). Helv. paediat. Acta, 13, $432-454$.

lichen Weizenmehleffekt bei der Cöliakie. 2. Die Wirkung der enzymatischen Abbauprodukte des Gliadin. Ibid., 14, 124-140.

Laster, L., and Ingelfinger, F. J. (1961). Intestinal absorption. Aspects of structure, function and disease of the small-intestine mucosa. New Engl. J. Med., 264, 1138-1148, 1192-1200, 1246-1253.

Lifshitz, F., Klotz, A. P., and Holman, G. H. (1965). Intestinal disaccharidase deficiencies in gluten-sensitive enteropathy. Amer. J. dig. Dis., 10, 47-57.

Messer, M., Anderson, C. M., and Townley, R. R. W. (1961). Peptidase activity of biopsies of the duodenal mucosa of children with and without coeliac disease. Clin. chim. Acta, 6, 768-775.

Pittman, F. E., and Holub, D. A. (1965). Sjögren's syndrome and adult celiac disease. Gastroenterology, 48, 869-876.

Plotkin, G. R., and Isselbacher, K. J. (1964). Secondary disaccharidase deficiency in adult celiac disease (nontropical sprue) and other malabsorption states. New Engl. J. Med., 271, 1033-1037.

Rubin, C. E. (1960). Celiac disease and idiopathic sprue; some reflections on reversibility, gluten, and the intestine. Gastroenterology, 39, 260-261.

_, Brandborg, L. L., Flick, A. L., Phelps, P., Parmentier, C., and van Niel, S. (1962). Studies of celiac sprue. III. The effect of repeated wheat instillation into the proximal ileum of patients on a gluten free diet. Ibid., 43, 621-641.

Schwartz, M. K., Sleisenger, M. H., Pert, J. H., Roberts, K. E., Randall, H. T., and Almy, T. P. (1957). The effect of a glutenfree diet on fat, nitrogen, and mineral metabolism in patients with sprue. Gastroenterology, 32, 232-246.

Sheldon, W., and Lawson, D. (1952). The management of coeliac disease. Lancet, 2, 902-905.

Smith, I. (1960). Chromatographic and Electrophoretic Techniques, 2nd ed., vol. I. Chromatography. Heinemann, London.

van de Kamer, J. H., and Weijers, H. A. (1955). Coeliac disease. V. Some experiments on the cause of the harmful effect of wheat gliadin. Acta paediat. (Uppsala), 44, 465-469.

van Roon, J. H., and Haex, A. J. C. (1960). Clinical and biochemical analysis of gluten-toxicity. II. Clinical experiments on patients suffering from idiopathic steatorrhoea after the administration of bromine treated performic acid oxidized polypeptides originating from wheat gluten. Gastroenterologia (Basel), 94, 227-235. 